\title{
Discussion essay
}

\section{Bestaat het Afrikaanse denken? Bestaat Afrika? Schets voor een publieke discussie ${ }^{1}$}

\begin{abstract}
Thirty years after Said's critique of orientalism, which was closely followed by Mudimbe's deconstruction of Africa as a colonial invention, Africanists have yet to solve their identity problem. Do they form a discipline? Or does each Africanist primarily belong to one discipline (history, anthropology, linguistics, literature and political sciences, and so on) each with its own method and object, each making the scientific claim to universality, that is, of transcending regional and cultural differences? If this is the case, then why should there be a study program called 'African studies' at all? Is there actually anything African to study? Is 'African thought' not a figment of our European, exoticising imagination? Is the continent itself not artificially delimited? The issue of regionally defined disciplines, or 'area studies', has recently become more acute in academia as the dominance of the positivist methodology has been increasingly felt and the humanities find themselves (again) on the defensive. The following essay can be read as an open letter, inviting students to infuse the debate with some fresh insights unhampered by academic jargon. The occasion for the debate is a previously published interview with scholars on the idea of 'African thought'. The idea is absurd, both geographically and genetically. Yet, this essay argues, one generation after the first postcolonial wave, we can think of at least two levels at which Africa does exist: the social(-political) and the cultural(-historical). Both meanings of Africa shift the burden of proof to those deconstructing the concept. The paper is in Dutch and addresses a Dutch-speaking audience. It begins and ends with some intricate connotations of 'Black' (zwart), 'race' (ras) and 'African thought' (Afrikaans denken) that are characteristic of the Dutch language and Flemish society in particular.
\end{abstract}

Bestaat het Afrikaans denken? Om kort te gaan: nee.

Waarom? Het is verkeerd om te beweren dat mensen met Afrikaanse genen geboren zijn met een bepaald soort denken. Het is bovendien een racistisch idee om erfelijke kenmerken zoals huidskleur te associëren met een bepaalde cultuur en denkwijzen. Daarom is elke inhoudelijke uitspraak over Afrika en Afrikanen problematisch. De tenen van de Afrikanist, of student Afrikanistiek, gaan krullen bij het horen van een zin die begint met 'Afrikanen zijn...' Vul zelf maar in. Afrikanen zijn zus of zo? Nee.

Achtergrond: lees het themanummer van n'go magazine, Volume 22, maart 2015, met als titel 'Het Afrikaanse denken en doen'. http://echoscommunication.org/nl/2015/03/25/ngo-n22/. 
Maar met dit antwoord maken we er ons als Afrikanisten te snel vanaf. Het bij een nee laten is doen alsof de vraag geen context nodig heeft om beantwoord te worden. Onder 'het' en 'Afrikaans' en 'denken' kan men meerdere dingen verstaan. In sommige gevallen is de uitspraak niet aanvaardbaar of legitiem, maar in andere gevallen wel. We overlopen de meest in het oog springende gevallen.

Ten eerste, het bepaald lidwoord 'het' in 'het Afrikaans denken' kan bedoeld zijn om het enkelvoud te benadrukken: er is slechts één Afrikaans denken. In het Engels zou men dit vertalen als 'the African way of thinking', de Afrikaanse denkwijze. Het bestaan van zoiets is een vergaande stelling, die gemakkelijk kan weerlegd worden door de feiten. Denk alleen al aan de veelheid van kosmologieën of wereldbeelden, dus denkwijzen, die men op het Afrikaanse continent vindt, alsook in de Afrikaanse diaspora in de rest van de wereld. Zoiets mag je niet zeggen dus.

Maar 'het' kan evenzeer de bepaaldheid als doel hebben, en om die reden contrasteren met het onbepaalde lidwoord 'een'. Het bepaalde lidwoord kan verwijzen naar een gekend concept, Afrikaans denken, waarover discussies bestaan met een zekere voorgeschiedenis, die politiek, literair en academisch geworteld zijn, of in de populaire cultuur leven. Voorbeelden zijn la pensée africaine en Black Thought. De bekende Afrikanist Achille Mbembe hield bijvoorbeeld onlangs een toespraak met de titel 'Can Black Thought be Raceless?' Is het mogelijk 'zwart' te denken zonder te verwijzen naar ras of huidskleur, of zonder zelf die eigenschap te hebben? In het Nederlands kan dergelijk gekend concept best aangehaald worden door hoofdletters te gebruiken zoals in het Engels. Het Afrikaans Denken: als eigennaam is het legitiem. Merk tevens op dat in het Engels het lidwoord wegvalt om deze algemene categorie aan te duiden. In het Nederlands blijft de 'het' staan en is die enkelvoudig om op het ene geheel van discussies te duiden met de gekende naam. De vertaling van de Franse uitdrukking la pensée africaine luidt: de Afrikaanse 'gedachte', wat ook doelt op 'de Afrikaanse zaak'. De gedachte of het denken aan Afrika en de Afrikanen, zonder cultuurspecifieke inhoud, slaat op het politieke belang van emancipatie dat betrekking heeft op alle Afrikanen, waarvan sprake verderop. In het Nederlands kent men het pan-Afrikaanse denken van de Afrikaanse Unie. In die betekenis is de titel 'het Afrikaans denken' legitiem, dus zonder hoofdletter ' $\mathrm{D}$ ' in het derde woord. Even legitiem is een titel met dezelfde drie woorden die gewoon verwijst naar de discussie in deze paragraaf.

Er is nog een andere manier waarop de uitspraak moet kunnen. Ook hier betreft het de invulling van de bepalende 'het'. Het Afrikaanse denken kan slaan op al het denken in het geografisch gebied omschreven als Afrika. Het bestaan daarvan kunnen we moeilijk ontkennen. Daarbij zal veelheid (in plaats van eenheid) gesuggereerd zijn. In dat geval is de omschrijving 'het Afrikaans denken', zonder hoofdletters, ook legitiem. Vergelijkbare uitspraken betreffen de Afrikaanse economie, het Afrikaanse eten, klimaat, verleden, muziek, enz. De lezer voelt nattigheid zodra die termen alles op één hoopje (genaamd Afrika) smijten en de diversiteit uitsluiten (bijv. bij eten: er bestaan veel voedselpatronen op het continent). Het n'go artikel geeft de gelegenheid om uit te zoeken, aan de hand van de context geschapen door de uitspraken erin, welke van de bovenstaande invullin- 
gen van 'het' de kop van het artikel beoogt. De geïnterviewden wijzen op het gevaar van veralgemening. Op de voorpagina van het tijdschrift staat niet toevallig 'Afrika: veelheid van denken en doen', alsof de redacteur wilde aangeven de boodschap in de interviews begrepen te hebben.

De tweede 'het' brengt ons bij het tweede woord van de drie: wat verstaan we onder Afrika, en dus Afrikaans? De geografische omschrijving is een eerste mogelijkheid. Deze invulling van Afrikaans denken is niet racistisch. Zoals in het voorbeeld van het bepalende lidwoord daarnet: er is denken te vinden op het continent (bijvoorbeeld in verhalen, liederen, filosofieën, in de media), en er is handelen te vinden, ook allerlei politieke en andere systemen van handelen, economische groei, en zo verder, die allemaal Afrikaans te noemen zijn. Maar de omschrijving (extensie) van dit adjectief is moeilijk af te bakenen. Wat telt als geografische grens? Is het continent de natuurlijke grens? De Sahara woestijn? Elke keuze is willekeurig (arbitrair) en zal op weerstand stuiten. Voor sommigen is het belangrijker wat de mensen zelf vinden: zien Noord-Afrikanen zich wel als Afrikaans? Naar verluidt vinden de Noord-Afrikanen die ten Westen van Egypte leven de referentie naar de Maghreb juister. Dan beperken we ons beter tot 'Sub-Saharaans' Afrika, of best: tot Afrika ten zuiden van de Sahara (Dat klinkt toch iets minder etnocentrisch dan 'Sub-Sahara': 'onder' de Sahara omdat het zo op onze noordgerichte kaarten staat). Maar daartegen zullen sommigen reageren dat bij beide termen aan 'Zwart-Afrika' gedacht wordt als belangrijkste referentiepunt voor Afrika, dus verwijzend naar de huidskleur waardoor de oude term 'ras' sluiks terugkeert. In ieder geval blijkt de geografische betekenis van Afrika niet noodzakelijk samen te vallen met de gebruikelijke.

Dat brengt ons bij de tweede mogelijkheid, een genetische categorie. Dergelijke 'Afrikaansheid' is evenmin eenduidig te bepalen, en blijkt alweer arbitrair. Wetende dat volgens de genetica alle mensen uiteindelijk afstammen van een Afrikaanse moeder, zouden we in gradaties van Afrikaanse verwantschap moeten spreken: hoe langer geleden of hoe meer generaties terug (begin maar al te kiezen!) de emigratie gebeurde, hoe minder Afrikaans bijvoorbeeld. Maar vanaf welke generatie trekken we de grens van wel of niet Afrikaans? De keuze is willekeurig. Een ogenschijnlijk objectieve oplossing is te verwijzen naar de huidskleur. Zodra de genetische verwantschap met Afrika zichtbaar is in de huidskleur wordt die persoon Afrikaans? Pech dan voor de broer uit een gemengde familie die er blank uitziet: alleen zijn zus met lichtbruine huid is Afrikaans. Zo arbitrair is de biologische/genetische categorie 'Afrika'.

Wat hebben we tot hiertoe vastgesteld over de categorie 'Afrika'? Hanteren we die biologisch of genetisch dan kunnen we niets voorstellen bij zoiets als Afrikaans denken. Aan de hand van huidskleur of afstamming kunnen we iemands overtuigingen niet afleiden. Kennis, cognitie en ideologie volgen uit opvoeding, cultuur, geschiedenis. Gebruiken we de categorie 'Afrika' geografisch dan hebben we een redelijk objectief criterium om het denken aldaar af te bakenen. De vraag rijst echter of er aan die plaats verbonden opvattingen en overtuigingen bestaan. Op eenzelfde plaats kan het denken een graad van homogeniteit vertonen, al is het zeker zo dat de kans daartoe kleiner wordt, hoe groter de betreffende regio is. Afrika is wel een zeer grote regio. Om daarover veralgemenende uit- 
spraken te doen wordt een hachelijke onderneming (zoals blijkt uit het n'go artikel) maar het is niet verboden te proberen. Men kan bijvoorbeeld in grote lijnen patronen ontwaren door de vergelijking te maken tussen verschillende continenten.

$\mathrm{Er}$ is echter nog een derde betekenis van Afrika, de sociaal-politieke categorie, die onze hele redenering op zijn kop zet en de bewijslast verschuift naar degene die beweert 'dat Afrika niet bestaat'. 'Afrika' wordt door veel Afrikanen zelf gebruikt om te verwijzen naar een gedeeld lot. Men moet van heel goede huize zijn om dit gebruik van de term te verwerpen, laat staan te verbieden. Dit verbieden als niet-Afrikaan, zogenaamd uit ethische overwegingen of politieke correctheid, is paternalistisch en getuigt vooral van weinig historisch besef. Het is vergelijkbaar met het verbieden van het woord 'arbeider' op grond dat niet alle arbeiders dezelfde sociale situatie hebben en dus niet onder eenzelfde noemer te vatten zijn. Welnu, arbeiders delen bepaalde belangen. Hoe deze belangen te verdedigen als arbeiders zich niet als groep kenbaar kunnen maken? Een eeuw geleden beschikten ze niet over dezelfde rechten als de burgerij. In de wekelijkse kerkdienst wilden de notabelen en fabriekseigenaars graag doen geloven dat er slechts één gemeenschap bestond waartoe allen hoorden, de geloofsgemeenschap onder God. Hoe dit religieus, economisch en politiek verbond doorbreken? Het concept arbeider (inclusief arbeidersklasse en proletariaat), hoe vaag gedefinieerd ook, was noodzakelijk om hun gedeelde belangen aan te duiden en hun maatschappelijke emancipatie mogelijk te maken in een arbeidervijandige omgeving.

Hetzelfde geldt voor de vrouwenemancipatie in een vrouwonvriendelijke maatschappij. Deze emancipatie wordt onmogelijk zodra het concept 'vrouw' ontmoedigd wordt, of 'gedeconstrueerd'. Sommige gender-specialisten zijn zo ver doorgeschoten in hun deconstructie dat zij de term 'vrouw' verwerpen vanwege het geïmpliceerde essentialisme, namelijk de suggestie dat er een essentie van vrouwelijkheid zou bestaan. In 'de vrouw' wordt het dualisme van de seksen man en vrouw verondersteld en daarin schuilt toch seksisme, stellen zij. Dat noemt men zichzelf in de voet schieten. Net zoals bij de fabrieksarbeiders die onderdrukt werden, hebben vrouwen te kampen met negatieve discriminatie in de samenleving, thuis en op het werk, die vaak verborgen en onbewust is. Deze discriminatie kan niet worden tegengegaan als men de getroffen categorie niet mag benoemen. Positieve discriminatie van de getroffenen, via bewuste ingrepen ter verbetering van hun lot, kan enkel door hen te benoemen. Alleen zo kan het evenwicht via beleid hersteld worden.

Als we kijken naar de argumentatie van de deconstructivisten, dan ontdekken we het misverstand. De 'derde' betekenis beoogt een sociale categorie. Deze slaat niet op elk specifiek individu (elke vrouw of arbeider) maar algemeen op de collectiviteit (van vrouwen of arbeiders). Deze categorie wordt niet absoluut gedefinieerd maar in relatie tot een andere categorie (mannen, fabriekseigenaars). Dus tegenover de gender-deconstructivisten zou de discussie ongeveer als volgt gaan. Akkoord, er bestaan tussenvormen in gender, biologisch of sociaal, dus er is inderdaad geen absoluut onderscheid te maken. Maar het onderscheid is relationeel. En het is niet individueel maar collectief. Zoals de arbeidersklasse verschilt van de burgerij verschilt de categorie vrouw van de categorie 
man. Vrouwen delen, sociaal gezien, bepaalde belangen. Dit is niet hun keuze maar het gevolg van de samenleving met zijn sociale structuur die machtsrelaties vormt. Met taal, en indien nodig nieuwe concepten, benoem je de verschillen en relaties die uit de sociale structuur volgen. Wetenschap moet hierbij helpen, om bewust te maken van nauwelijks erkende patronen in onderdrukking. Anders laat je onrecht bestaan. (De rechten van de derde gender maken op hun beurt ook maar kans indien deze gender in taal bestaat).

Welnu dezelfde problematiek als voor 'arbeider' en 'vrouw' geldt voor het benoemen van Afrika. Toen Afrikaanse intellectuelen zoals Senghor en Damas bijna een eeuw geleden spraken van la pensée africaine hadden zij het lot van kolonialisme, racisme en slavernij op het oog dat hun voorvaderen deelden en waar zij zelf of hun verwanten en vriend(inn)en nog onder leden. Door Afrika te benoemen konden ze iets aan de discriminatie doen en het racisme aan de kaak stellen. De 'Black power' in de VS in de Ig6os is van dezelfde teneur. Welke blanke durft het aan hun concept van Black, 'zwart', te verwerpen omdat het ras zou impliceren? Geef toe, volgens onze initiële argumentatie - de eerste betekenis - getuigen deze bewegingen van een zekere graad van racisme door huidskleur te verbinden met een bepaald soort denken. Het gaat weliswaar om een gedachtegoed, namelijk dat zwarten onderdrukt worden en zich moeten emanciperen. Er zijn zwarten die hier niet mee akkoord gaan, bijvoorbeeld zwarte republikeinen die vinden dat Amerika alle kansen biedt aan zij die zich inzetten. Toch zullen weinigen ontkennen datje met 'Black' en 'Africa' menselijke relaties benoemt en dat deze relaties een zekere ongelijkheid kennen die wereldwijd uit de sociale structuur volgen.

Door expliciet te stellen 'Afrika bestaat' gaat de Afrikanist in tegen de ontkenning van die ongelijkheden. 'Black' verwijst naar een sociale realiteit waartoe in vele gevallen onderdrukking hoort. Er is het dagelijks racisme in de straat, op de huurmarkt en jobmarkt tegen mensen met een donkere huidskleur. De stereotypering van Afrika gebeurt volop in de media en in het tooggesprek: magie en mensenoffers worden aangehaald als teken van gebrek aan beschaving in de Afrikaanse dorpen. Meer onschuldig, de kleurrijke ongeplande, bricolerende stad zou duiden op levensvreugde maar ook op nood aan (Westerse) organisatie en onderwijs. Los je deze stereotypering op door de term 'Afrika' te deconstrueren en zelfs te verbieden? Integendeel, je laat de grote massa in het ongewisse over hun nefaste beeldvorming en veronderstellingen. Evenmin los je het probleem van de beeldvorming op door op veilig te spelen en de term Afrika te beperken tot een geografische entiteit, kunstmatig afgelijnd op een kaart. Dan ben je geen Afrikanist maar een wetenschapper werkend op de regio Afrika. Is een bioloog die slakken in het Congolese regenwoud bestudeert een Afrikanist? Niet vanzelf. Het suffix 'ist' duidt op iets extra, op een focus of perspectief dat gericht is op Afrika. In de praktijk betekent dit dat de Afrikanist mensen bewust maakt van patronen die onrecht in stand houden. Uit ervaring met onze opleiding weet ik dat veel studenten Afrikaanse Talen en Culturen uitkomen voor deze derde betekenis van Afrika door de regiostudie te kiezen in plaats van de sociaalwetenschappelijke discipline Sociale en Culturele Antropologie. Het klinkt paradoxaal maar als je achter de sociaal-politieke betekenis van Afrika staat, dan opteer je voor de regiostudie in plaats van Pol\&Soc. Je wil investeren in taalverwerving en kennis 
over culturen en lokale context. Om die context te bestuderen - en nu komt de volgende paradox - gebruikt de Afrikanist sociaalwetenschappelijke methodes van kwalitatief onderzoek, waaronder participerende observatie en diepte-interviews.

Met de derde, 'sociale' betekenis verdedigen we de belangen van een categorie die door sociale omstandigheden ontstaan is - een categorie die niet sui generis (uit zichzelf) bestaat maar de facto (door de feiten) ontstaan is. Het continent Afrika is politiek en economisch geïntegreerd in het mondiale systeem van macht- en welvaartstructuren. De bewijslast verschuift naar degene die beweert dat de categorie Afrika niet de facto bestaat.

Maar de belangrijkste betekenis van Afrika, volgens de Afrikanist, moet de vierde zijn, de culturele betekenis. Met cultureel bedoelen we cultuurhistorisch. 'Afrika' verwijst dan naar het bestaan van culturele systemen (denkwijzen, wereldbeelden en praktijken) die niet primair bepaald zijn door het Westen, en dit in een regio van de wereld die geografisch min of meer afgebakend is. Sprekers durven op basis van die betekenis bijvoorbeeld zeggen dat bepaalde plaatsen die geografisch tot het continent horen zoals Windhoek (Namibië) en Kaapstad (Zuid-Afrika) "niet echt Afrika zijn”. Het geeft aan dat deze betekenis meteen de meest controversiële is. Een Afrikanist die werkt op Kaapstad is toch niet minder Afrikanist dan degene die zich op het leven in een Malinees dorp toelegt? Dat is zeker zo. Tegelijk moet men durven toegeven dat het stukje Afrika van beide onderzoekers cultureel heel sterk verschilt. Normaal gezien weten die onderzoekers dat en doen zij die contextuele toelichting, wat hun onderzoek even Afrikanistisch maakt. Om deze nogal onzinnige discussie te vermijden leidt men uit Afrika beter geen variabele eigenschap af, zoals 'Afrikanistisch' of 'Afrika-gehalte'. Wie dat toch doet moet opletten dit gehalte niet toe te kennen op louter geografische basis. Het cultuurhistorische aspect mag niet genegeerd worden.

Historisch bekeken, enkel in de tijd en dus zonder uit te gaan van het bestaan van cultuur, kent elke plek zijn verhaal. Aan elk gebied, al dan niet eenduidig afgebakend, kan een keten van gebeurtenissen toegeschreven worden. De pertinente vraag van de vierde betekenis is echter of deze geschiedenis meer is dan een arbitraire samenstelling van gebeurtenissen. Is er een cultuurgeschiedenis? We gaan er hierbij vanuit dat cultuur staat voor een geheel van elementen of delen (opvattingen, overtuigingen, normen en praktijken onder meer) die door leden van een groep aangeleerd zijn en overgedragen worden. Bij zoiets immens als een continent moeten we eerst de vraag in het meervoud stellen: zijn er cultuurgeschiedenissen? Met andere woorden, zijn er in Afrika gehelen te vinden, die cultuur genoemd worden, waarvan de geschiedenis kan bestudeerd worden omdat de gebeurtenissen daar als delen naar het geheel verwijzen en slechts via die relatie begrijpelijk worden?

Antropologen noemen dit de holistische dimensie van cultuurstudie. We doen aan langdurig etnografisch onderzoek om fenomenen te begrijpen in het licht van hun relaties met de rest van de cultuur. Inzicht in het onderliggende wereldbeeld en de sociale structuur helpt ons uitstijgen boven de archivering van chronologische feitjes. Het helpt ons begrijpen waarom bijvoorbeeld Sukuma boeren niet akkoord gaan met het historisch oorzakelijk verband dat buitenstaanders veronderstellen tussen de danscompetities 
die de Gika en Galu secties van de Sukuma gemeenschap tegenover elkaar uitspelen, en de gelijkaardige oude Beni danscompetities op andere plaatsen in Tanzania. De boeren herkennen iets a-historisch in hun praktijk, namelijk de kanalisatie van geweld via duale structuur, die ze ook in andere praktijken toepassen. Op zich volstaan historische antecedenten niet om de significantie van die structuur in de cultuur te ontwaren. Vandaar de voorkeur van antropologen voor een holistische methodologie.

Dus: kunnen we zoiets afbakenen als een cultuurgeschiedenis? Heeft Afrika als geheel een holistische dimensie? De gemakkelijkheidoplossing is nee te zeggen, namelijk uit te gaan van één complexe wereldgeschiedenis die (al dan niet artificieel) opgedeeld wordt in regio's met ontelbare overlappende geschiedenissen. Hoe meer feiten je vergaart, hoe beter je kennis. Afrika zou dan niet meer zijn dan een kunstmatig afgelijnd onderdeel van de wereld, eentje waarvan weliswaar mag toegegeven worden dat het afwijkt van het Westen door minder technologische vooruitgang, tragere ideologische veranderingen, en een paar grote crises zoals slavenhandel en kolonialisme. De diversiteit aan (parallelle) systemen in Afrika, groter dan waar ook ter wereld, op vlak van besluitvorming (gaande van jagershorde tot chefferie, koninkrijk en Staat), handel (gaande van ruilhandel tot kapitalisme), religie (gaande van animisme tot monotheïsme) en verwantschap (zowel patrilineair als matrilineair en tussenvormen) kan de historicus er nog bij nemen als een historische toevalligheid. Dat geschiedenisschrijvers te kampen hebben met verschillende, zelfs tegengestelde visies op eenzelfde gebeuren, van groepen of individuen, en als wetenschapper ook hun eigen perspectief hebben dat het beeld van de werkelijkheid vervormt, in dit geval van Afrika, dat kan men ook nog methodologisch behappen. Maar dat er meer dan één werkelijkheid en geschiedenis is; dat er een Westerse kijk bestaat met heel particuliere criteria van kennis en waarheid, waarbij bepaalde aspecten belicht worden en andere verhuld; en dat er in Afrika zulke andere perspectieven zijn die ons begrip zelf van geschiedenis zouden veranderen, dat is een stap te ver voor de meeste historici, en voor wetenschappers in het algemeen.

Nochtans is dat de implicatie van de cultuurhistorische betekenis. Afrika staat voor een unieke reeks kaders waarmee de wereld wordt ervaren, ingevuld met opvattingen, praktijken en sociale instituties die historisch gegroeid zijn, lokaal en ook globaal, en die als geheel een evolutie doormaken waarbij ervaringen geselecteerd en geaccumuleerd worden en een groep mensen cultureel op elkaar betrokken zijn. Afrika is een totaal van die gehelen, die bovendien verschillen van het Westen. Bestaat zoiets ontastbaar, onzichtbaar als een geheel, een cultureel geheel zonder dewelke de vele verzamelde feitjes niet begrepen worden, ze hun lokale context zeg maar 'ziel' missen? Het is de nulhypothese waartegen we best zeer goede argumenten hebben alvorens hem te verwerpen of negeren. Dat laatste is echter waar de Westerse geschiedenis van uitgaat. Het komt de Westerling goed uit om 'Westen' en 'Afrika' te deconstrueren en verwerpen. Het alternatief is het perspectief van de binnenstaander te moeten kennen, wat een methodologische verschuiving inhoudt naar een andere tak, de antropologie en etnografisch veldwerk. Om zo'n zelfopoffering te vermijden liggen er ethische argumenten klaar: 'Afrika is een uitvinding van de Europese imperialisten.' 
Het gevaar van Afrika-deconstructie (met een uitspraak zoals 'Afrika bestaat niet') is dat men de culturele kolonisering ontkent. Experten die dit proces ontkennen, zijn medeplichtig aan de voortwoedende kolonisering, en dit in de hoogste graad, want zij spreken met de (gesalarieerde) pretentie van expertise over cultuur. Omdat zij de verantwoordelijkheid hebben gekregen in het Westen om de lokale situatie en "eventuele 'cultuur' die men ontmoet" te beschrijven en vertegenwoordigen voor het concipiëren van overzeese samenwerkingen en ontwikkelingsprojecten is hun negeren van die cultuur onomkeerbaar. Helaas, de experten zien hun ontkenning van cultuur als geheel, en hun reductie van cultuur tot de deeltjes en elementen van hun studie, niet als problematisch. Zij merken bijvoorbeeld niet hoe het verbieden en uitsterven van initiatie de lokale reproductie van de kosmologie onmogelijk maakt. Zij worden tegen hun wil de sleeper cells van het neokolonialisme. Wanneer aan hen op een cruciaal moment, in de media of in een internationaal rapport, gevraagd wordt of culturen in gevaar komen door de internationale interventies, dan volgt hun hoongelach: 'culturen sterven niet, ze veranderen'.

Varianten op hetzelfde thema zijn uitspraken als: 'Afrika is een verwerpelijk concept want houdt het beeld van primitieve culturen in stand, en van een achterlijke rurale samenleving terwijl het een evenzeer bruisende urbane is', 'Afrikanen hebben zelf gekozen om hun oude tradities te verlaten', 'Afrika is niet traditioneel: als magie heden nog gepraktiseerd wordt is het moderne magie, wat niets te maken heeft met de primitieve magie', 'Het Westen is een uitvinding, die bewijst hoe uniek we onszelf vinden, terwijl mensen eigenlijk onderling overal evenveel verschillen', 'Cultuur is een neoliberale uitvinding voor de toeristenmarkt, en voor controle van minderheden door de Staat', 'Het cultureel verschil is een excuus voor xenofobie en racisme', 'Cultuur als een wereldbeeld dat de vele delen tot een zinvol geheel smeedt is een fabeltje, zoals goden, even onzichtbaar als onbestaande'.

Al deze terugkerende uitspraken hebben een ethische boodschap die sommige progressieve geesten aanspreekt. Helaas verraden de uitspraken - de ene al wat fouter dan de andere - ook onjuiste en stereotiepe veronderstellingen over cultuur, traditie en magie. Bij correct gebruik van de termen verwijzen traditie en magie naar fenomenen die in alle samenlevingen in een of andere vorm voorkomen. In de bovenstaande uitspraken wordt een ethische connotatie toegevoegd. Een typisch achterliggende gedachte is de veronderstelling van (niet-Westerse) culturele tradities als obstakel voor emancipatie. De veronderstelling is sociaal progressief, maar cultureel conservatief. De veronderstelling houdt de cultureel gelijke behandeling tegen, die nodig is in deze multiculturele mondialiserende eeuw, en die de sociaal gelijke behandeling uit de vorige eeuw kan opvolgen. Cultureel gelijke behandeling (cultural equity) betekent niet dat elke culturele praktijk aanvaardbaar is (denk aan vrouwenbesnijdenis, slavernij, lijfstraf), net zomin als social equity gelijke kansen betekende voor elke toenmalige sociale categorie (gaande van slavenhandelaars over daglonerronselaars tot despoten). Er moeten keuzen gemaakt worden. Maar de spanning tussen sociale en culturele progressiviteit kan niet ontkend worden. De sociaal gelijke behandeling betekende ingaan tegen cultureel aanvaarde structuren. Die strijd mag niet teruggedraaid worden. Dus cultural equity is maar mogelijk als we 
social equity behouden, wat niet kan zonder ten gronde in publiek te durven debatteren over cultuur, over gebruiken en overtuigingen. De bovenstaande stellingen van Afrikadeconstructivisten pogen net het debat te vermijden.

De meeste uitspraken om Afrika te deconstrueren snijden hout wanneer ze het politieke misbruik van concepten (hier Afrika en cultuur) aan het licht brengen. In een tweede stap nemen ze echter verkeerdelijk aan dat het politieke misbruik van concepten iets zegt over het al dan niet bestaan van datgene waarnaar de concepten verwijzen, namelijk dat het misbruik hun niet-bestaan zou bewijzen. Akkoord, 'cultuur' is artificieel wanneer het wordt opgevoerd door politieke groeperingen als hun identiteit, als te beschermen folklore, en als basis voor rechten van minderheden (indigenous rights). Zowel voorstanders als tegenstanders van deze cultuurpolitiek vergeten echter dat cultuur ook het geheel van onuitgesproken kaders is dat gehanteerd wordt door de mensen zelf in lokale gemeenschappen. Cultuur in die eigenlijke zin van het woord ligt niet voor het grijpen want leeft vooral onbewust. Pas wanneer tot bewustzijn gebracht en bevattelijk gemaakt tot een min of meer coherent geheel kan cultuur de visie van de buitenstaander én binnenstaander in een nieuw perspectief plaatsen en eventueel op zijn grondvesten doen daveren. Dit fundamenteel, zeg maar antropologisch type van cultureel verschil blijft een geheim voor velen bij gebrek aan veldwerkervaring ter plaatse of in de Afrikaanse diaspora.

Het Westers verschil wordt maar duidelijk wanneer men als onderzoeker kan vergelijken. Na intens veldwerk, via taalverwerving en gestage participatie in bijvoorbeeld rituele initiaties ter plaatse, wordt duidelijk hoe sterk de Westerse hegemonie is, in onszelf, en hoe homogeniserend de scholen, universiteiten, kerken en overheden hebben opgetreden sinds meer dan een eeuw, met de transplantatie van die ene kosmologie, ethiek, psychologie, sociologie, geschiedenis en zo verder, naar de schoolcurricula in de minst geglobaliseerde 'uithoeken' van de wereld. De door ons gesteunde roep om meer onderwijs in de ontwikkelingslanden klinkt dan vals: het komt neer op snellere culturele kolonisering van andere gemeenschappen.

Wat is de kans dat de lokale bevolking zal protesteren tegen de onderdrukking van hun cultuur? Zijn zij daar eigenlijk om bekommerd, gezien de christelijke bekering van velen en de tolerantie daaromtrent bij de anderen? Zijn ze eigenlijk bewust van de verdwenen structuren en de wegkwijnende reproductie van hun cultuur over de laatste drie generaties? Wat is de kans dat ze zullen beweren dat hun cultuur gebrekkig is vertegenwoordigd in het maatschappijmodel dat in hun land wordt geïmplementeerd? Degenen onder hen die zouden kunnen protesteren want onze taal spreken en de academische bagage hebben, voelen zich het minst aangesproken. Hun denken stemt immers in grote lijnen overeen met dat van ons en van zowat iedereen met ongeveer dezelfde opleiding. Het zijn uitzonderingen die tegen hun eigen opvoeding en opleiding ingaan. Ik wilde toevoegen: uitzonderingen 'zowel hier als daar, bij ons en bij hen' - maar dat zou de kans verhogen dat die woorden tegen mij gebruikt worden als duidend op een 'wij/zij denken'. Diezelfde beschuldiging mogen de protesten tegen culturele kolonisering ook verwachten! "Is hun protest niet gestoeld op uitvergroting van het culturele verschil, dus op cultuuressentialisme, ja verborgen racisme?" Het is waar, elke onderdrukte minderheid die iets wil doen 
aan de onrechtvaardige situatie zaait tweedracht. Degenen die profiteren van de ongelijke behandeling en die hun macht via de status quo willen behouden, zullen die mondige minderheid beschouwen als 'wij/zij' denkers.

Universiteit is een machtsinstituut dat universele kennis beoogt. Culturele inhoud die de mogelijkheid daarvan tegenspreekt zal ze niet snel aanvaarden. 'Bekering' is geen overdreven begrip om de overtuiging te vatten van de wetenschapper die objectieve, universeel geldende waarheid nastreeft en tevreden terugkijkt op het verleden door de vooruitgang te benadrukken naar hogere gradaties van waarschijnlijkheid via het verzamelen van data. Maar wat is die gradatie waard als de basispremissen ervan niet universeel zijn, dus substitueerbaar zijn? Viveiros de Castro is een antropoloog die het cultureel verschil ten volle toelaat in zijn werk. Hij beschrijft het animisme van Amerindianen die de vele schepselen op Aarde zien als verschillende zijnswijzen van eenzelfde geest, in tegenstelling tot het universitair natuurwetenschappelijk wereldbeeld, waar alle mensen deelachtig zijn aan eenzelfde natuur maar even zovele subjecten zijn met een unieke geest. Dit cultureel verschil bevindt zich op een zodanig fundamenteel niveau, van basispremissen over het bestaan der dingen (ontologie genoemd), dat het niet weerlegd kan worden door de natuurwetenschap. In mijn onderzoek van de relaties tussen gift, offer, schuld en magie bij Sukuma boeren stel ik gelijkaardig diepe tegenstellingen vast met de leefwereld en het wereld- en mensbeeld waarin ik ben opgegroeid. Van hen leerde ik dat er slechts één productiewijze bestaat, genaamd het leven, waarvan jij, ik en alle mensen deel uitmaken. Het Westers verhaal is dat van superdiversiteit, en daardoor seriële culturele conflicten, moderniseringstress en sociale ongelijkheden die onvermijdelijk zouden zijn op grond van verdienste, kapitaal of regionaal verschil qua cultuur en productiewijze.

Kortom, deconstrueer je 'Afrika' - bijvoorbeeld uit angst voor misbruik van het begrip zoals stereotypering door je landgenoten - dan mis je meteen een unieke kans om je eigen wereldbeeld te laten daveren op zijn grondvesten. Vele uitgesproken 'postkoloniale' Afrikanisten missen momenteel die kans om zich door Afrikaanse leefwerelden fundamenteel bevraagd te voelen. Zij verkiezen de multiculturele diversiteit, die je overal in de wereld vindt en die Afrika niet uitzondert, boven de mogelijkheid van een confronterend cultureel verschil, een andere ontologie.

Wanneer we als westerlingen de vraag stellen over Afrika, komen we meteen uit op de volgende, die we misschien eerst moeten stellen: bestaat er zoiets als het Westen? We zouden graag ontkennend antwoorden, omdat we daarmee alvast onze arrogantie lijken te temperen. Maar een nog betere strategie voor dit laatste is de historische feiten onder ogen te zien, en te onderkennen dat het Westen tot op zekere hoogte een cultuurgeschiedenis heeft, met toevallig enkele problematische aspecten. Er zijn vele redenen voor die aparte cultuurgeschiedenis. Laten we beginnen met de culturele redenen. Precies omdat wetenschap, verspreid via vele kanalen vanuit universiteiten, een zekere homogenisering van kennis in de hand werkt is er een culturele globalisering gebeurd in het meest welvarende deel van de wereld, dat het eerst profiteerde van de technologische evolutie. De culturele invloed zou anders gelopen zijn indien landen zoals India en China een grotere rol hadden gespeeld, wat we wel mogen verwachten deze eeuw. Maar het imperialisme 
van de negentiende eeuw kwam uit Europa en de globaliseringsgolf na de tweede wereldoorlog kwam uit de VS, een land dat zowat dezelfde voorouders als ons had en uit dezelfde tradities putte om er tot op zekere hoogte in combinatie met de Afro-Amerikaanse tradities van de bevrijde slaven en de Indiaanse populatie iets innovatiefs van te maken, zij het gedomineerd door dezelfde 'Westerse' premissen als in Europa. Daarom mag men spreken van 'het Westen'. De leidende klassen en intellectuele elites van dit amalgaam van landen met zeer verschillende sociale structuren, waaronder grote boerenpopulaties die zich niet betrokken voelden bij de stedelijke intellectuele evoluties, eigende zich het etiket beschaving toe. Dit proberen ze nog steeds, zij het op zachtere wijze, om één waarheid op te leggen aan Afrikaanse gemeenschappen, tot op vandaag artificieel overlapt door koloniale landsgrenzen in staten die het lot van die gemeenschappen bepalen zonder hierin ooit gekend te zijn. De natie-staat is de enige juiste bestuursvorm volgens het Internationale recht, dat ook hierin duidelijk We(s)ters is. Het is in contrast met 'onze' vrij homogene culturele realiteit dat de diversiteit in de rest van de wereld opvalt, en vooral in Afrika met zijn duizenden talen en culturen bezuiden de Sahara. In relatie tot Afrika is het Westen cultureel homogeen. De culturele hegemonie van deze homogenie doorbreek je niet door ze dood te zwijgen, onder andere door de term 'Westen' te verbieden (omdat het te veel eer voor ons verleden zou zijn en de oude imperialistische pretenties zou in stand houden). Afrika staat voor datgene dat cultureel daarvan verschilt en aldus - in de feiten en vooral onbewust - weerstand biedt aan de hegemonie, die de wereld tracht te veroveren. Het is vanuit die optiek, de cultuurhistorische betekenis en niet de geografische, genetische of sociaal-politieke, dat iets kon worden geopperd over het Afrika-gehalte van een plaats zoals Windhoek of Kaapstad. Ik denk nu voor het gemak aan een rijke 'blanke' buurt in zo'n stad - zonder te beweren dat degelijk Afrikanistisch onderzoek net daar niet de hele complexiteit van Afrika zou kunnen vatten! Maar dergelijke onderscheiden moeten kunnen. Ze worden betekenisloos, of gezien als fout, of worden verboden, een taboe, als we die vierde betekenis niet onderkennen. Het Afrika dat men cultuurhistorisch op het oog heeft, brengt de hegemonie in verlegenheid, doet de reus soms twijfelen en misschien, nadat de sleeping cells uitgeteld zijn, eens een keer wankelen.

In mijn ervaring voelen studenten Afrikanistiek dit aan, niet altijd uitgesproken (omdat hun leefwereld, school en de media hen daar niet bepaald in helpen vanwege die hegemonie die echt is) maar intuïtief. Wij als lesgevers moeten hen in die intuïtie sterken. Met Afrika, en het Afrikaanse denken, zeg je een heleboel, maar ook dat: die weerstand tegen de ene maatstaf die ons van huis uit wordt meegegeven. De vierde, culturele betekenis van Afrika is de meest pregnante wat mij betreft want duidt op een continent met een geschiedenis, dat op vele plaatsen tegelijk culturele innovaties heeft geaccumuleerd en zijn eigen waarden, overtuigingen en opvattingen heeft ontwikkeld. In relatie tot het globaliserende We(s)ten is die relatieve onafhankelijkheid uniek (ik zeg relatief want er was ook culturele uitwisseling en deze gaat eeuwen terug). Voor mij staat die culturele betekenis meer voor Afrika dan het geheel aan historische gebeurtenissen, crisissen, hongersnoden, conflicten en regimewisselingen die we op het nieuws te zien krijgen. Het gevaar dat nieuwsfeiten en het discours over onder andere 'superdiversiteit' de eigenheid van Afrikaanse culturen voor ons uitvlakken is reëel. 
Momenteel grijpen een aantal nefaste ontwikkelingen tegelijk plaats die onze gevoeligheid voor dat gevaar doen slinken: de kortere veldwerkperiodes wegens publicatiedruk, het talig deficit bij onderzoekers in Afrika dat de overheersing van de lingua franca ten nadele van lokale talen alleen maar versterkt, het verdwijnen van subversief dekoloniserende cultuurantropologie door recuperatie van snufjes ervan in gevestigde wetenschappen en hun schoolvakken maatschappijleer en geschiedenis, de kwantificering in onderzoeksmethodes en de idealisering van het labo-model van datacollectie, de romantisering van kosmopolitisme en de schijnbaar heterogene stad ten nadele van het platteland voorgesteld als uniform, de profileringdrang van disciplines, vooral tussen humane en sociale wetenschappen en hun daaraan gepaarde specialisatie, formalisatie en verminderde zelfkritiek, de vermijding van inhoudelijke discussie en daardoor het populisme van de politieke correctheid en de woordenpolitie, de uitholling van het cultuurconcept onder druk van atomisme, positivisme en het natuurwetenschappelijk model, en het ongemak over de traagheid en meerlagigheid van contextualisering, ondanks de aanzwellende roep om slow science.

Zo komen we uit op de derde term, 'denken'. In het Engels betekent thought de verzameling van al het denken (met een lidwoord ervoor wordt het een gedachte, iets helemaal anders: bestaat 'een' typisch Afrikaanse gedachte?). In die zin van een verzameling, vertaald als African thought, moet 'het Afrikaanse denken' kunnen. Door 'en doen' toe te voegen in de titel probeert het n'go artikel deze betekenis te benadrukken: al het denken en doen op het continent. Maar de interviews met Afrikaanse en andere intellectuelen in dat artikel hengelen toch naar een culturele homogeniteit, naar het voorbeeld van die van Westerlingen. Na een waarschuwing tegen essentialisme pogen ze de interviewer wel te plezieren met wat algemene culturele 'Afrikaanse' patronen zoals het belang van de gemeenschap, man/vrouw complementariteit en spiritualiteit. Maar ze weten dat daarbinnen weer veel differentiatie te vinden is, zodat het moeilijk 'patronen' kunnen genoemd worden. Onderling, weet ik uit ervaring, mijden intellectuelen niet om zich cultureel als Afrikaan te manifesteren en zich daadwerkelijk zo te voelen. Ten minste als ze zich in Europa bevinden. Het is niet zozeer een identiteitskwestie, van zich te identificeren met de groep die herkenbaar verschilt van de plaatselijke waar je te gast bent. Het is eigenlijk ook niet omdat Afrika cultureel zo duidelijk te specificeren valt. Nee, de reden is zoals daarnet vermeld dat het Westen bijna belachelijk uniek is, of beter: 'anders' is, en intern bijna overal hetzelfde, als je het vergelijkt met Afrika. Dankzij wetenschap, school, universiteit en media is er een kritisch denken verspreid sinds de Verlichting, soms omschreven als rationalisme, dat voor ons een bevrijd denken is maar in die zin wel uniform is. Dit denken is afgestemd op onze nogal eenvormige consumptiemaatschappij, voortstuwend van de ene mode naar de andere, op vlak van stijl, concepten, zeden, seksualiteit, spiritualiteit, omgang, technologie, en zoverder, terwijl het ook sommige categorieën uitsluit daarvan en deze als allochtoon definieert. Met die in een geschiedenis van zelfverheerlijking ingebedde 'civilisatie' kun je moeilijk samenvallen als Afrikaan. In relatie tot die gepretendeerde civilisatie is er wel degelijk een Afrika, zelfs een Afrikaans denken en doen. Dat is de cultuurhistorische realiteit van Afrikaan te zijn in Europa en de VS. Dat is waarom de 
leden van de Afrikaanse diaspora elkaar bijna altijd vinden in het Westen, daar een soort solidariteit ervaren of minstens een zekere identiteit aannemen en delen in plaats van deze te vluchten. Het maakt het een uitdaging, tevens zinvol en speciaal - alternatief? om over Afrika te leren binnen ons universitair stelsel.

Dit brengt ons tenslotte toch weer bij de derde, sociale betekenis, die nauw verbonden blijkt te zijn met de vierde, culturele. Maak de vergelijking met de vorige kwestie. Hoe stereotypen doorbreken zoals de verzorgende vrouw, de onverantwoordelijke arbeider, en de primitieve Afrikaan? Is het waar dat door categorieën en hun benaming te verbieden de kans op stereotypering en discriminatie kleiner wordt? Nee, de capaciteit om de categorie af te lijnen wordt er alleen door bemoeilijkt. Daardoor wordt de discriminatie minder voorspelbaar en kan deze als een ongeleid projectiel een bredere groep treffen, maar daarom verminderen de stereotypering en discriminatie niet, en zijn beide al zeker niet gemakkelijker tot bewustzijn te brengen. Antropologen geven een duidelijk signaal aan de samenleving door woorden te bannen die het cultuurimperialisme van het Westen en het denigreren of romantiseren van anderen in stand houden: 'primitief' en het gerelateerde 'stam' en 'magie'. Maar deze negatieve beweging moet samengaan met een positieve beweging die vervangende begrippen oplevert voor de fenomenen waarnaar die oude begrippen inadequaat verwezen. Anders lijkt het bannen een negeren, een louter ethische daad van de woordenpolitie die niet op feiten is gebaseerd. In sommige gevallen zoals bij 'magie' hebben antropologen de term weer ingevoerd, niet langer om Afrika of het Westen af te zonderen maar om beide aan elkaar te relateren; om in dit geval de magische praktijken te vergelijken in alle regio's van de wereld en in alle maatschappelijke domeinen met inbegrip van technologie. Dan blijkt magie een soort technologie te zijn waar de moderniteit naar snakt.

In Vlaanderen zijn we er zonder twijfel trots op van het woord ras uit onze woordenschat gebannen te hebben. Ik zou het niet anders willen. Het woord is te beladen vanwege de rassentheorie die in de vorige eeuw culmineerde in het drama van de Holocaust. Maar voor ons lijkt het alsof het gebruik zelf van het woord racistisch is, en dit oordeel niet zou afhangen van hoe het gebruikt wordt. Zijn Amerikanen racistisch omdat ze races onderscheiden op basis van huidskleur? Doen zwarte Amerikanen dit ook uit racisme? Of uit onwetendheid, vanwege hersenspoeling door de dominante, 'blanke' cultuur? Met alle respect maar de Vlaamse monocultuur kan moeilijk concurreren met de multiculturele Amerikaanse waar de hiphop cultuur zegeviert en de rassenkwestie expliciet aangekaart wordt, zoals onlangs weer met het hitalbum van Kendrick Lamar. Hij zingt over het lot van Blacks heden in de VS, en is niet bang om 'ras' te expliciteren.

Er leven veel Afro-Vlamingen in Vlaanderen. Maar er lijkt in Vlaanderen nog niet genoeg multicultureel-kritische massa aanwezig te zijn voor hen om zich alzo kenbaar te maken. De term 'Afro' laat nochtans toe om de zaken duidelijk te stellen, dat veel mensen handelen in functie van dergelijke uiterlijke kenmerken en dat net daarom ras een sociale realiteit wordt die men niet kan of mag ontkennen. 'Race' en 'culture' zijn twee verschillende zaken, zegt men in het Engels. In het Nederlands is de term 'ras' te beladen om zo'n duidelijk anti-racistische uitspraak te doen. Zou het niet kunnen dat het verbod om 
deze term te gebruiken net het verborgen racisme in Vlaanderen mogelijk maakt? Hiphop liefhebbers weigeren de woordencensuur. Hun raps schuwen niet het gebruik van 'race' noch van het meer beledigende woord 'niggar', die als teken van samenhorigheid of geuzennaam gelden. Deze artiesten zijn politiek bewust genoeg om een doordachte en gerechtvaardigde keuze te maken. Ze benoemen de gedachten van racisten als een antidotum, om ze te ondergraven. Zeg ras om racisme te bestrijden, namelijk de gelijkstelling van ras en cultuur tegen te gaan. (Zeg cultuur om culturalisme te bestrijden, namelijk de gelijkstelling van cultuur met biologisch lidmaatschap van een groep tegen te gaan?) De onmogelijkheid om ras of cultuur eenduidig te definiëren doet er niet toe. De woorden zijn ankerpunten voor de associatie van bepaalde ideeën. Het zijn instrumenten binnen een breder maatschappelijk project van emancipatie.

De representatie van een andere cultuur verbieden verhindert mensen om hun representaties te verbeteren en laat toe dat illegitieme representaties clandestien verspreid geraken. Hoe de zaak van die cultuur dienen als men zich blindstaart op de vraag of en hoe die cultuur afgelijnd kan worden? Laten we een laatste keer terugkeren naar de analogie. Cultureel en historisch gezien is er een realiteit genaamd vrouw. De vrouw verbeeld in literatuur, muziek, dagelijks discours, en dus ook negatief verbeeld in situaties van sociale ongelijkheid, is echt. Zij ondergaat de echte gevolgen van de beeldvorming in de samenleving en hieraan kan niet verholpen worden zonder haar als categorie te benoemen. Hetzelfde geldt voor Afrika.

Afrika bestaat. En dit op meerdere gronden. Afrika staat voor een regio met een unieke geschiedenis. Afrika bestaat sociaal-politiek, als een belang dat een bepaalde categorie mensen zowel binnen als buiten die regio treft. Maar Afrika is ook een culturele realiteit, van praktijken, tradities, ervaringskaders en ideële structuren die op verschillende plekken op het continent ontstonden en zich vaak relatief onafhankelijk van het imperialistische Westen ontwikkelden. Dit impliceert voor de buitenstaander dat het begrijpen ervan niet evident is. Afrika blijft in die zin - laten we het maar even rap zeggen wars van alle zelfcensuur - ontembaar. Historici beseffen dat zij een Westerse versie van de Afrikaanse geschiedenis bieden. Een linguist en sociolinguïst die formele analyses doen van taaluitingen, weten dat ze bij gebrek aan contextuele kennis geen uitspraak kunnen doen over inhoud, over de betekenis van die uitingen. Antropologen zitten in dezelfde positie door aan te geven dat het adequaat vertalen van culturele verschillen naar het publiek toe een blijven zoeken is, zowel relatief is als holistisch, altijd in relatie tot andere delen van het geheel.

Problemen duiken pas op wanneer antropologen het holisme laten varen en feitjes verzamelen, kennis menen te accumuleren en op atomistische wijze vergaren, bijvoorbeeld over een politiek systeem of globalisering in verschillende veldwerksites (multisited ethnography). Wegens tijdgebrek en publicatiedruk doen ze korter veldwerk, waardoor ze beweringen doen over fenomenen zonder deze te beschouwen vanuit de lokale ervaringskaders. Ze hebben die 'perspectieven' niet zelf beleefd en kunnen die fenomenen dus niet begrijpen zoals de lokale bevolking. Zodra het besef van cultureel onbegrip verdwijnt en dus geen moeite meer gedaan wordt om uit de eigen ervaringskaders te treden en met die andere in 
dialoog te treden, wordt het beeld van Afrika kunstmatig. Zonder begrip vanuit de lokale context verwordt antropologie tot navelstaren, tot een eurocentrisch experiment, kortom iets kunstig, naar het voorbeeld van Renzo Martens' kunstwerk 'Enjoy poverty".

\section{Conclusie}

De kop van het n'go artikel is veelledig (het, Afrikaans, denken) en meerlagig (vier maal Afrika). Bestaat Afrika? Niet als 'samenleving' of als 'een' soort samenleving, want daarvoor zijn de verschillen te groot tussen de regio's zoals tussen de Maghreb en het Afrika bezuiden de Sahara, of het westelijke Afrika van de oude koninkrijken, het Bantoesprekende in midden en oostelijk Afrika, en de moderne staat Zuid-Afrika.

Toch bestaat Afrika, maar dan als volgt.

I. Op grond van conventie, als naam van het continent: de geografische entiteit aangeduid op onze wereldkaart. Op basis daarvan spreken we van Afrikaanse culturen, Afrikaanse talen (met inbegrip van het Engels en Frans daar aangetroffen) of van een Afrikaanse samenleving.

2. Arbitrair, als genetische categorie van afstamming die een (overeen te komen) aantal generaties teruggaat.

3. De facto, als sociale categorie van mensen die bepaalde belangen delen omdat ze dezelfde gevolgen dragen van racisme, kolonisering en cultuurimperialisme.

4. Relatief, als culturele categorie van denkwijzen en praktijken die zich lange tijd onafhankelijk van de Westerse hegemonie ontwikkeld hebben.

Bestaat het Afrikaans denken?

I. Nee, er is niet één denkwijze gedeeld door alle Afrikanen.

2. Ja, als verzamelnaam voor al het denken (en doen) op het Afrikaans continent.

3. Nee, tenzij als omschrijving van het sociaal-politieke thema van pro-Afrikaans of pan-Afrikaans denken en 'de Afrikaanse gedachte', een streven naar emancipatie tegen heersende discriminatie.

4. Nee, tenzij als omschrijving van het cultuurhistorische thema: de vele Afrikaanse culturen vormen een geheel, relatief gezien, door hun verschil met de homogene denkwijze verspreid in het Westen.

Met dit laatste punt zeggen we 'nee en ja'. Nee want Afrika kent vele culturen die herkenbare gehelen vormen, dus Afrikanen verschillen onderling in hun denken (over wereld, mens, familie, gemeenschap, genderrelaties, en zo verder). Maar ja, samengenomen zijn deze ideeën sterk verschillend van de redelijk homogene denkwijze verspreid in het Westen die een culturele hegemonie vormt.

We moeten ons als Afrikanisten ernstig afvragen of de postkoloniale verwerping van het cultuurverschil als een zogenaamd koloniale uitvinding geen continuering van die hegemonie is.

Koen Stroeken

Department of Languages and Cultures, Ghent University 